\begin{tabular}{ll}
\hline 論 & 説 \\
\hline
\end{tabular}

聴神経腫瘍における聴力保存の基礎と臨床

神崎仁・小川郁・松永 達雄*

\title{
Basic and Clinical Aspects of Hearing Preservation in Acoustic Neuroma Surgery
}

\author{
Jin Kanzaki and Kaoru Ogawa \\ (School of Medicine, Keio University) \\ Tatsuo Matsunaga \\ (Kawasaki Municipal Hospital)
}

Hearing preservation is one of the ultimate goals of acoustic neuroma (AN) surgery. In this paper, we present the surgical results of hearing preservation surgery in our department, as well as our recent basic research on hearing preservation in AN surgery.

Subjects consisted of $95 \mathrm{AN}$ patients who underwent hearing preservation surgery via the extended middle cranial fossa approach and the middle cranial fossa approach. The overall hearing preservation rate was $51 \%$. From the analysis of surgical results, we discussed the indications for hearing preservation surgery and the evaluation of pre- and post-operative hearing. In addition, we proposed a new classification system for pre- and post-operative hearing evaluation.

We also present our basic research on "the relationship between cochlear blood flow and electrocochleographic findings during cochlear ischemia", and "the morphological studied of the VIII cranial nerve in AN patients". The changes in N1 and N2 in electrocochleography depended on the cochlear blood flow. Thus, we can estimate the degree of cochlear ischemia using the electrocochleography. Furthermore, the impairment of cochlear blood flow and cochlear nerve damage could be distinguished by the electrocochleographic findings. The morphological findings of the VII cranial nerves of AN patients demonstrated tumor invasion in approximately $67 \%$ of the cochlear nerves, suggesting that total tumor removal together with hearing preservation could not be performed in these patients. In addition, gliosis in the transitional region of the cochlear nerve in AN patients was observed, which might lead to a change in capillary distribution. Angiogenesis was also found in tumor tissues from the cochlear nerve. These morphological findings indicated that the impairment of cochlear blood flow may be easily induced by manipulation during tumor removal, especially those around the transitional region.

Key words : hearing preservation, acoustic neuroma, cochlear blood flow, gliosis, angiogenesis 


\section{はじめに}

著者 (J.K.) は1988年本誌に聴神経腫瘍 (AN) の聴力 保存に関する諸問題について論説した1). 本項ではその 後に我々が行った AN に対する聴力保存手術を基に， 最近の聴力保存に関する臨床的ならびに基礎的研究の結 果を概説する.

臨床的成績として聴力保存の適応㧊よび成績，特に聴 力保存された聴力の質の評価などについて自験例を中心 に述べてみたい，基礎的研究として(1)術中に起こる蝸 牛血流障害時の蝸牛血流動態と蝸電図所見，（2）側頭骨 標本に拈ける内耳動脈の解剖拉よび聴力保存非適応例の 手術中に採取した蝸牛神経の組織学的, 免疫組織学的所 見について述べる.

\section{臨床成績}

\section{1. 対 象}

1976年より1995年 4 月までに脳神経外科との協力で 390例の AN 手術を行った。これらのらち聴力保存手術 を行い, 術後 1 年以上の観察が可能であった95例を対象 とした.

\section{2. 手術法}

中頭蓋窩法 (33例) 打よび拡大中頭蓋窩法正型 (62例)を 用いた．手術法の詳細は紙面の関係上省略するが，手術 法の分類とそれぞれの要点を表 1 にまとめた22.

術中モニタリングとして顔面神経に対しては針筋電図 と筆者らが開発した刺激兼用のマイクロ器具を用いた ${ }^{33}$. 螖牛神経の術中モニタリングとしては聴力保存手術を開 始した初期には蝸電図とABRを用いたが，最近では $\mathrm{ABR}$ と第UIII神経複合電位 (CAP と略す)を用いている.

3 . 聴力保存の適応
我々は対側聴力が正常な一側性 ANに対しては会話 域平均聴力 (PTA) $50 \mathrm{~dB}$ 以内, 語音弁別能 (SDS) $50 \%$ 以上の例 $(50 / 50$ と略す)を聴力保存の適応としている. しかし初期には 50/50 以下の例に対しても腫瘍の大きさ が $20 \mathrm{~mm}$ 以下の例では経験を積むために聴力保存手術 を行った．現時点では，術前聴力が 50/50の基準を満た せば，腫瘍の大きさに拘わらず，聴力保存を試みること にしている. しかし，反対側に補聴器を用いても日常会 話が困難な感音難聴を有する症例や Neurofibromatsis II (NF2) の症例では腫瘍の発育を観察し，増大傾向を 示す例には radiosurgeryを行っている.

これまで反対側に人工内耳を行い， AN 側の手術を行 った例や4)，AN 側の蝸牛神経を温存し，その側に人工 内耳を行った報告5) も散見されるが，AN の術後に必ず 人工内耳の適応となる保証はない，術者によっては AN の全例に聴力保存を行うべしとする人もいる6) 8). しかし，このような治療方針は一般的には対側耳の聴力， 顔面神経麻痖やその他の合併症の危険度とのバランスで 決められるべきものと考える.かつては AN の大部分 が一側性であり, 対側聴力には問題がないこと, 聴力保 存適応例が少ないことから聴力保存手術の必要性につい て疑問視されていたが9), MRI の普及と共に聴力良好例 が増加しつつあり, 聴力保存手術は避けて通れないもの となっている. 今後は聴力保存の予後の予測と有用聴力 保存率の向上のための方法，技術が開発されねばならな い.

\section{4. 聴力保存率}

通常, 聴力保存率は測定可能な聴力が保存された症例 の全聴力保存手術施行例に対する割合で示される．自験 例では95例中48例(51\%)であった ${ }^{10)}$ 。この保存率は著者

表 1 拡大中頭蓋窩法の分類

\begin{tabular}{lccc}
\hline \hline & I & 拡大中頭蓋窩法 type & III \\
& not indicated & not indicated & indicated \\
Hearing preservation & done & done & not done \\
Labyrinthectomy via MCF & not done & done \\
$\begin{array}{l}\text { Separation of } \\
\text { the superior petrosal sinus }\end{array}$ & & & done \\
$\begin{array}{l}\text { Incision of } \\
\text { the cerebellar tentorium }\end{array}$ & not done & done & done
\end{tabular}


らの以前の報告と同様でありまたこのような手術を行 っている各国の報告例と比較しても遜色ないものである. しかし，著者らは単に聴力保存率のみで手術の成否を論 ずるべきではなく，保存した聴力の質をより問題にすべ きと考えており，保存された聴力の結果を各術者間で比 較するための新しい分類法を第 2 回の AN 会議(1995年 4 月, パリ)の聴力保存のパネルで提案した. しかし各 演者の聴力保存の結果の分類法は統一されず，今後の課 題として残された。

5. 聴力保存手術により保存された聴力の分類 私どもが提案した分類は Gardner ら ${ }^{11)}$ と Shelton ら ${ }^{12)}$ の分類の修正案である.このよらな分類は第一に 簡単で覚えやすいものでなければならない，従来いくつ かの分類が提案されていたが11) 15), 使いやすいのは Shelton ら ${ }^{12)}$ の分類であった。 しかし，この分類でも serviceable hearing (50/50 以上)の中に $30 / 70$ の good hearingを含みまた measurable hearingは30/70と 50/50 の両者を含むなど，論文を読むときに混乱するこ とがあった．そのために表 2 に示した様に $30 / 70$ をクラ
ス A，31〜50/51〜69を B，それ以下をC，反応なしを Dとすることを提案した。この案は Gardner ら ${ }^{11)}$ の分 類とほぼ同様であるが，彼らの分類ではCがさらに2 ラスに分かれている．我々はこの点を不要と考光，保存 聴力を 3 つのクラスに分けるのが覚兄やすく，各施設間 の比較も簡単にできるものと考えた. 今後, 施設間での 聴力保存の質を比較するために，このような分類を用い て評価することが必要である.

\section{6. 提案した分類による自験例の成績}

表 3 に術前の分類で $\mathrm{A} \sim \mathrm{C}$ にあった聴力が術後どのク ラスになったかを示した。このようにみると術前にAま たはBであった75例のらち，術後に同様にAまたはBで あった例は23例(31\%)にすぎないことが分かる．単なる 聴力保存率にはC クラスが含まれているために聴力保存 率としては良くなっていることを考慮する必要がある.

\section{7. 聴力保存可能力否汃の予測}

聴力保存手術の可否には術者の経験や技術が関与する. また経験，技術がある一定のレベルに達していたとして も, 術中の蝸牛神経と内耳道内の血管の状態拉よびこれ

表 2 聴力保存手術に括ける聴力の分類

\begin{tabular}{lcccc}
\hline \hline Class & PTA(dB) & SDS(\%) & Gardinerの分類 & Sheltonの分類 \\
\hline A : good to excellent & $0 \sim 30$ & $70 \sim 100$ & 1 & good \\
B: serviceable & $31 \sim 50$ & $50 \sim 69$ & 2 & serviceable * \\
C: poor & $51 \sim 100$ & $49 \sim 2$ & 3,4 & measurable * \\
D: no measurable & & & 5 & \\
$*$ & : Shelton ら \\
& diner ら ${ }^{11)}$ の分類の class 1, 2, 3, 4 を含む.
\end{tabular}

表 3 新しい分類法による術前後の聴力の比較

\begin{tabular}{|c|c|c|c|c|c|c|c|c|}
\hline \multirow{2}{*}{\multicolumn{2}{|c|}{$\begin{array}{c}\text { Preoperative hearing } \\
\text { Class }\end{array}$}} & \multicolumn{4}{|c|}{ Postoperative hearing } & \multicolumn{3}{|c|}{ HP rate } \\
\hline & & A & B & c & $\mathrm{D}$ & & $\mathrm{N}$ & $\left(\frac{8}{0}\right)$ \\
\hline A & 48 & 15 & 5 & 7 & 21 & $A+B+C$ & 27 & $(56.3)$ \\
\hline B & 27 & - & 3 & 9 & 15 & $B+C$ & 12 & $(44.4)$ \\
\hline C & 20 & - & - & 9 & 11 & $\mathrm{C}$ & 9 & $(45.0)$ \\
\hline
\end{tabular}


らと腫瘍との関係を術前に予測する検査はないため, 聴 力保存可能か否かの予測はなかなか困難である. 聴力保 存の予後の良好な因子としては腫瘍の大きさ, 術前聴力 レベル, 患側 $A B R$ 所見, 男性, 術終了時のモニタリン グで ABR が術前と比較して悪化の少ないこと,などが 報告されているが12116) 18)，いずれも確実な指標とはい えない。これまでの経験からは内耳道に限局した聴力良 好な例を早期に診断し聴力保存手術を行らことが, 保存 された聴力の質の向上につながると考えられる. 自験例

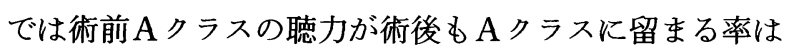
48例中15例(31\%)であった(表 3 )。この率は術前Bクラ スのものが術後も B クラスに留まる率よりも有意に高く, 聴力良好な例の浪らが手術侵襲に対しても受傷性が低い ことが推測される.

\section{8. 保存された聴力の長期予後}

聴力保存手術を施行された症例の保存聴力が長期的に 維持されるか否かが，このような手術法を今後も行らか 否かの鍵を握っているといってもよい，

自験例 45例の追跡では少なくとも 4 年間はPTA, SDS に大きな変化は認めなかった，それ以後の追跡例 は少なくなるが，より長期的にも保存聴力は安定してい るといえる。我々はPTA で $15 \mathrm{~dB}$ 以上, SDS で $20 \%$ 以上の変化を聴力悪化と定義しているが, 術後保存聴力 の悪化は再発例 2 例に認められたのみであった．このこ とょり, 定期的な術後の聴力検査は再発の早期診断法と しても意義があると考えている. Shelton $5^{19)}$ は長期的 にSDS が反対側より急速に悪化することを報告し，こ の原因が腫瘍摘出後に内耳道に充媜した側頭筋の線維化 による血管の狭窄と推測している．そのため彼らは充填 物を筋肉から脂肪に変更している。しかし，自験例では 筋肉と脂肪のいずれでもこのような傾向は認められなか った。な拉，Shelton ら 19)を除くと，術後保存された聴 力には大きな変化はないとするものが多い20) 22).

\section{9. 聴力保存と QOL}

一側のみの高度難聴でも対側聴力が正常範囲内にあれ ば，日常生活上，支障は少ないが，方向感や騒音下の会 話で支障をきたすこともある．しかし，AN の術後の後 遺症としてこの程度の障害のみで他の脳神経症状がなけ れば，手術の結果は受容されるであろう。しかし，人間 の要求は次第に高くなるので, もし聴力の良い段階で䛦 断されたのであれば，聴力を保存して欲しいと願うのは 誰しも同じであろう。また，特に問題となるのは対側に
も何らかの原因による高度難聴があったり，現在聴力は 良好でも NF2 のために将来聴力低下が予想される場合 である、いずれの場合も現時点では聴力保存を保証した 手術を行うことは困難であるので，もし聴力保存に対す る要求が強ければ腫瘍の発育速度を観察しながら経過を みるか, radiosurgery のいずれかを考虑することになる. しかし, 後者でも聴力が確実に保存される保証はない。 顔面神経保存率が向上したように聴力保存率もあるレべ ルをでは上昇すると考穴ている。しかし顔面神経と異な り, 螖牛神経は後述するような transitional zone の脆弱 性を有するため, 神経扣よびその周囲に不可逆性の変化 が生じないらちに腫瘍が除去される必要がある。このよ らな蝸牛神経の病態は現在の聴覚検査では術前に推測で きない，腫瘍が小さく，腫瘍の発生から診断までの期間 が短い例では蝸牛神経の病変は軽微であると考兄られる ので, 小腫瘍の成績が良くなることは当然理解される. したがって，ある限られた例にのみ聴力保存の可能性が あることになる．現在はこの適応と限界を明らかにする ための過程にあるといえるであろう、QOL の立場から は術前と同じ就業が可能で, 生活上の支障のないことが 第一であるので, 聴覚以外の脳神経障害, 特に頻度の上 からは顔面神経機能の保存が最も重要である. 聴力保存 はこれらの目標が注ぼ達成されつつある施設で次の目標 として取り組むべき目標といえるもので，決して他の機 能より優先して行うべきものではない.

\section{術中に起こる蝸牛血流障害時の蝸牛血流動態と 蝸電図所見}

AN 手術に和ける聴力保存率の向上のためには個々の 症例に护ける難聴の病態を術前に明らかにし, 聴力保存 手術の適応症例を的確に選択し, さらには腫瘍摘出時に いかなる注意を払らべきかを知る必要がある。しかし， AN 飞执ける難聴は極めて多彩であり ${ }^{23)}$, その詳細な病 態を術前に明らかにできないことが多く, 聴力保存の適 応症例の難聴の病態を基にした選択法は今後の課題であ ると言える. 一方, AN 摘出に際しては術中聴力モ二タ

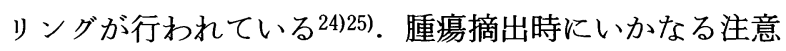
を厸らべきかを知るためには, 腫瘍摘出時の蝸牛神経や 内耳動脈の障害がそれぞれ術中モニタリングの情報にど のように反映するかを明らかにする必要がある.

本項ではANに扣ける難聴の病態の1つと考兄られ る蝸牛血流障害をとりあげ，モルモットを用いてレー 
ザードップラー法 (LD 法)により蝸牛血流をモニタリン グしながら前下小脳動脈 (AICA) を機械的に圧迫遮断す ることにより様々な程度の蝸牛血流障害を作成し，蝸牛 血流障害の程度が術中聴力モニタリングとして用いられ ている蝸電図の変化にどのように反映されるかについて 述べる ${ }^{26)}$.な括, 蝸牛血流障害の程度は残存血流量とし て示した.

\section{AICA 遮断時の蝸牛血流動態}

AICA を遮断しても全例で蝸牛血流量が減少するとは

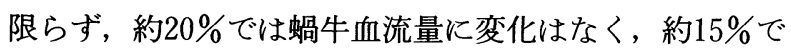
は一定の蝸牛血流量を維持できなかった. AICA 遮断に より蝸牛血流量が減少し, かつ遮断中一定の蝸牛血流量 を維持できた70例中 44 例 ( 3 分間遮断34例, 10 分間遮断 10例)では蝸牛血流量は AICA 遮断と同時に減少し, 解 除とほぼ同時に血流が回復した。遮断解除後に蝸牛血流 が初期値より一過性に増大する hyperemia を示すこと があり， 3 分間遮断例の $47 \%, 10$ 分間遮断例の $80 \%$ に認 められた。

モルモットなどの実験動物では AICA 領域の側副血 行路が豊富であり, またとの個体差も大きいことから, AICA 遮断による蝸牛血流障害の程度は様々である。 Randolf ら27)もAICA の遮断により蝸牛血流に変化を 認めたモルモットは約半数であり, 他の半数では初期值 の25〜50\%に減少したと報告している. Sugita ら ${ }^{28)} は$ モルモットの内耳道周囲の動脈の走行を観察し, AICA 扣よび内耳動脈の走行には個体差, 左右差が大きく, 内 耳動脈が直接脳底動脈より分枝する例も多いと報告して いる. したがって, AICAを遮断しても蝸牛血流に変化 が認められなかったモルモットでは内耳動脈が直接脳底 動脈より分枝するなど他の動脈系が蝸牛血流に関与して いた可能性も考兄られる。一方, Ren ら ${ }^{29)}$ は AICA 遮 断により蝸牛血流は約 $55 \%$ をで減少し，その後一定圧の 遮断にもかかわらず蝸牛血流は徐々に増加したことより， AICA 遮断による蝸牛血流の動的变化は側副血行路から 螖牛への血流が増加するためと考察している. 今回の検 討でAICA 圧迫の程度を調節することによって約 $63 \%$ のモルモットでほぼ一定の蝸牛血流減少を維持すること ができたことから，側副血行路そ介した蝸牛血流の調節 能の存在の他に, 遮断末梢側の AICA や内耳動脈の自 己調節能が関与していると考えられる。また，この自己 調節能はAICA 遮断解除後の hyperemia 飞も関係して いると考えられる。
2. AICA 遮断時の残存血流率と $\mathrm{N} 1, \mathrm{~N} 2$ の変化

AICA 遮断による蝸牛血流減少にともない $\mathrm{N} 1$ 潜時, $\mathrm{N} 2$ 潜時は徐々に延長し，N1 振幅も減少した. AICA 遮 断後 3 分間に $\mathrm{N} 1$ または $\mathrm{N} 2$ が消失した例は44例中それ

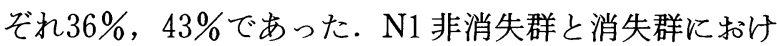
る残存血流率はそれぞれ $57 \% ， 37 \%$ であり，両群間に有 意差を認めた $(\mathrm{p}<0.01)$. N2 でも両群間に有意差を認め,

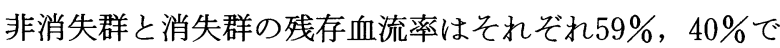
あった $(\mathrm{p}<0.01)$. AICA 遮断後 N1，N2 が消失するま での時間 (survival time) と残存血流率との関係をみると, 個体差は大きいものの，両者の間には相関関係が認めら れ $(\mathrm{p}<0.05)$, 残存血流率が低くなるほど N1, N2 の survival time も短くなる傾向があった.

次に 3 分間の AICA 遮断中に N1，N2 が消失しなかっ た例で遮断 3 分後の $\mathrm{N} 1$ 潜時, $\mathrm{N} 2$ 潜時, $\mathrm{N} 1$ 振幅の変化 率と残存血流率との関係について検討したＮ１潜時， $\mathrm{N} 2$ 潜時の変化率と残存血流率との間には汪㜔負の相関 が認められ $(\mathrm{p}<0.01)$, 残存血流率が低くなるほど N1 潜時, N2 潜時の変化率は大きくなった。これに対して $\mathrm{N} 1$ 振幅の変化率と残存血流率では両者の間には正の相 関が認められ $(\mathrm{p}<0.01)$, 残存血流率が低くなるほど $\mathrm{N}$ 1 振幅は減少する傾向があった(図 1 ).

これらの結果は $\mathrm{N} 1 ， \mathrm{~N} 2$ の変化がほぼ残存血流率に依 存することを示している. 図 1 亿示した回帰直線より 3 分間の血流遮断で $\mathrm{N} 1, \mathrm{~N} 2$ に変化を認める残存血流率の 閾值を求めると，それぞれ約 $80 \%$ であり，蝸牛の酸素予 備能は極めて少ないと考号られる. 蝸牛神経活動電位な どの蝸牛および蝸牛神経に関係する電気反応はいずれる 酸素依存性であり血流障害の影響を受けやすいことは既 に指摘されている30 32). しかし，これまでの報告では 血管遮断中の血流の変化について詳細な記載はなく, 血 流障害の程度と N1, N2 の变化の関係についての系統的 な解析はなされていない，今回の検討では蝸牛血流障害 の程度と $\mathrm{N} 1$ 潜時, $\mathrm{N} 2$ 潜時, $\mathrm{N} 1$ 振幅の変化の間に相関 関係が認められ，N1，N2 の survival time は N1 に比べ てN2 で短かった. 従って, これらのパラメータの変化 より臨床的にも蝸牛血流障害を定量的に予測することが 可能であるとい方る。また，N2 はN1 に比べて蝸牛血 流減少に対してょり敏感に反応すると考兄られた.

3. AICA 遮断解除後の N1, N2 の変化

残存血流率が $31 \sim 60 \%$ の 3 分間 AICA 遮断例15例と 10分間遮断例10例で N1, N2 の回復過程を比較した. 両 

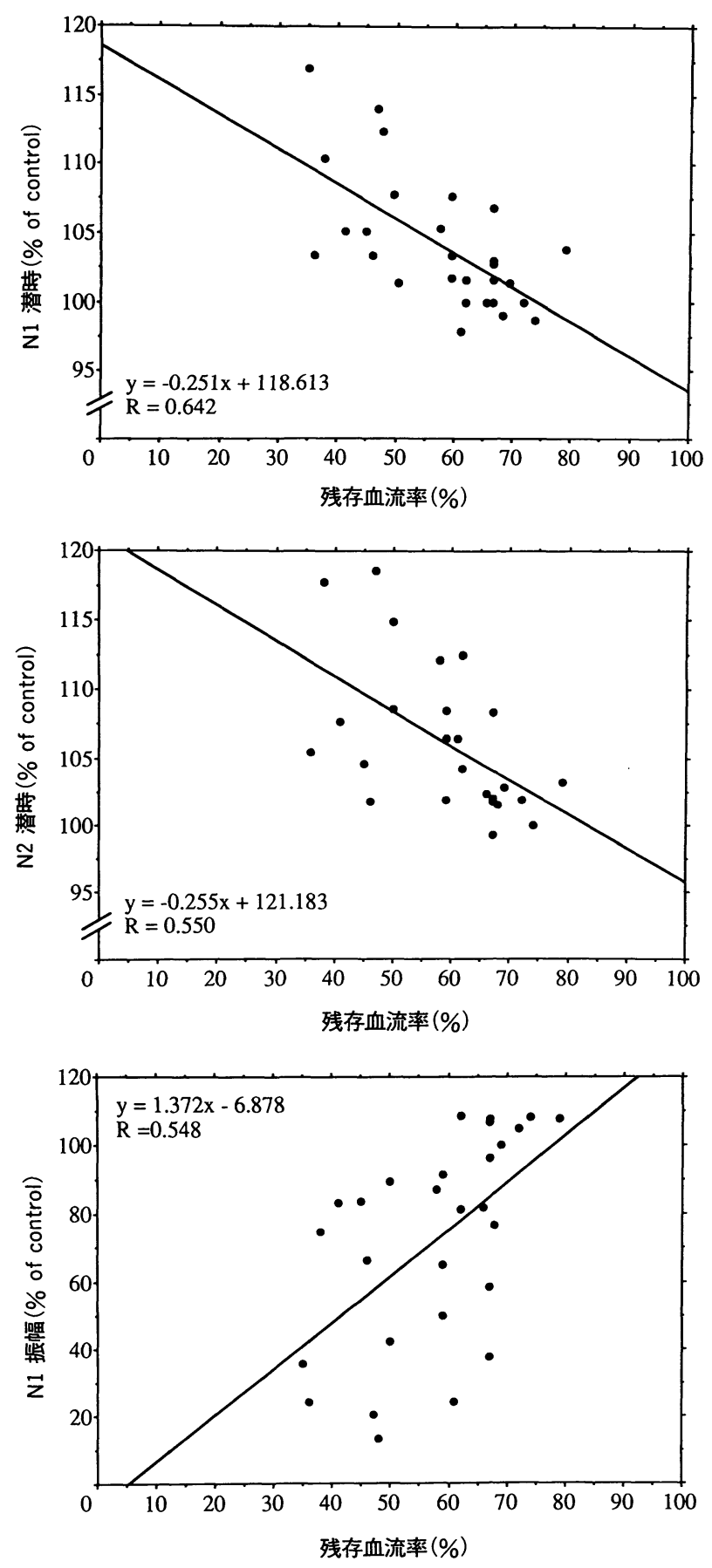

図 $1 \mathrm{~N} 1$ 潜時, $\mathrm{N} 2$ 潜時および $\mathrm{N} 1$ 振幅の変化率と残存血流率 との相関

control は遮断前の N1 潜時, N2 潜時および N1 振幅と した.

群の残存血流率はそれぞれ $42 \%, 41 \%$ で有意差はなかっ た. 遮断解除後, N1 潜時, N2 潜時は速やかに短縮し，
3 分間遮断群では解除後 180 秒で注核初期值まで回復し たが，10分間遮断群では 3 分間遮断群に比べて N1 潜時, $\mathrm{N} 2$ 潜時の回復は有意に不良であった。 N1 振幅は 3 分 間遮断群で遮断解除後, 初期值より増大し (supernormality) 平均 $113 \%$ まで達した。これに対して10分間遮断 群では遮断解除 180 秒後に一時初期值まで回復したが, その後再び減少し 20 分後の N1 振幅は $88 \%$ であった(図 $2)$.

蝸牛血流の hyperemia と N 1 振幅の supernormality を比較すると, hyperemia を示した例では N1 振幅も supernormalityを示したのに対して, hyperemiaを示 さなかった例では N1 振幅にも supernormality は認め られなかった $(\mathrm{p}<0.01)$.

低酸素による蝸牛組織障害の可逆性については既に多 くの組織学的検討がなされており，比較的短時間の anoxia でも有毛細胞やらせん神経節細胞などの蝸牛組 織には不可逆性の変化が生じるとされている31133)。一方, Kusakari ら ${ }^{34)}$ は20分間の遮断では EP, CM ともに完全 に回復したのに対して，N1，N2 は10分以下の遮断でも 不可逆的な変化を示す例があり，10分以上の遮断ではほ ぼ全例に不可逆的変化を認めたと報告した. 今回の結果 は Kusakari ら ${ }^{34)}$ の報告と同様であるが，残存血流率が 41 70\%でも 10分間の遮断では $\mathrm{N} 1$ 潜時, $\mathrm{N} 2$ 潜時, 振 幅に不可逆性の変化が生じる可能性が考兄られた.

遮断解除後, N1 振幅は初期值より増大し supernormalityを示した. Konishi ら ${ }^{32)}$ は 8 分以内の AICA 遮 断では遮断解除後に N1, N2 振幅も supernormalityを 示し, 8 分を超える遮断では N1, N2 振幅の supernormality は生じなかったと報告した．今回の結果でも 10 分間遮断では N1 振幅の supernormality は認められな かったが, 遮断解除約 3 分後に一時的に注ぼ初期值まで 回復したことは10分間遮断でも supernormality を生じ る機序が働いていることを示している。蝸牛血流の hyperemia と N 1 振幅の supernormality とに密接な関 係が認められたことより, AICA 遮断解除後の蝸牛血流 の hyperemia が蝸牛電気反応の supernormality $の 一$ 因 となっていると考えられた。

4. 術中聴力モニタリングへの応用

今回の検討結果より AN 摘出術中の内耳道操作によ り内耳動脈が障害された場合には蝸牛血流は直ちに減少 し，この蝸牛血流減少は術中モニタリングで用いられて いる蝸電図の $\mathrm{N} 1, \mathrm{~N} 2$ の变化に敏感に反映されると考兄 


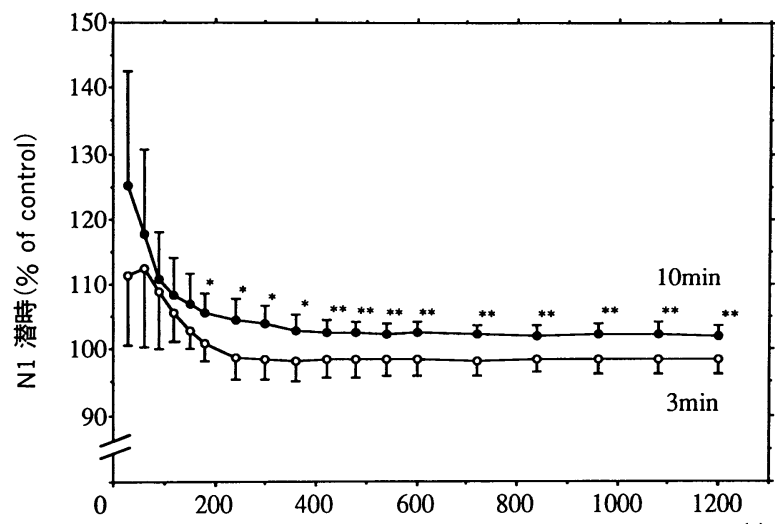

(s)

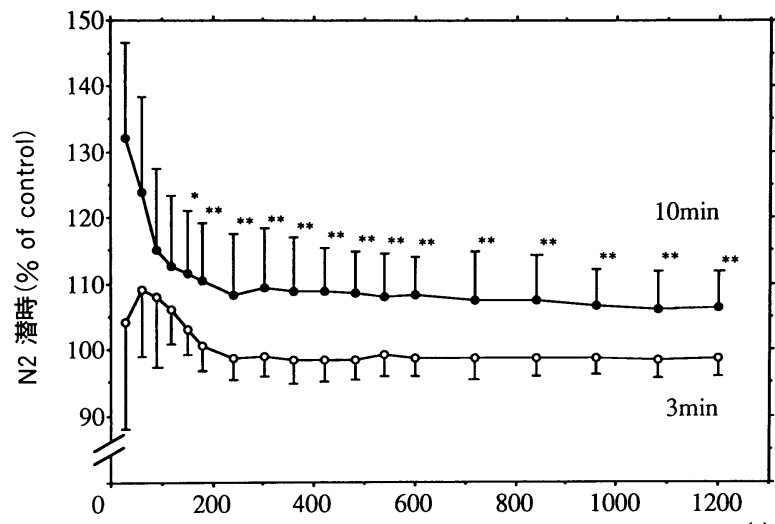

(s)

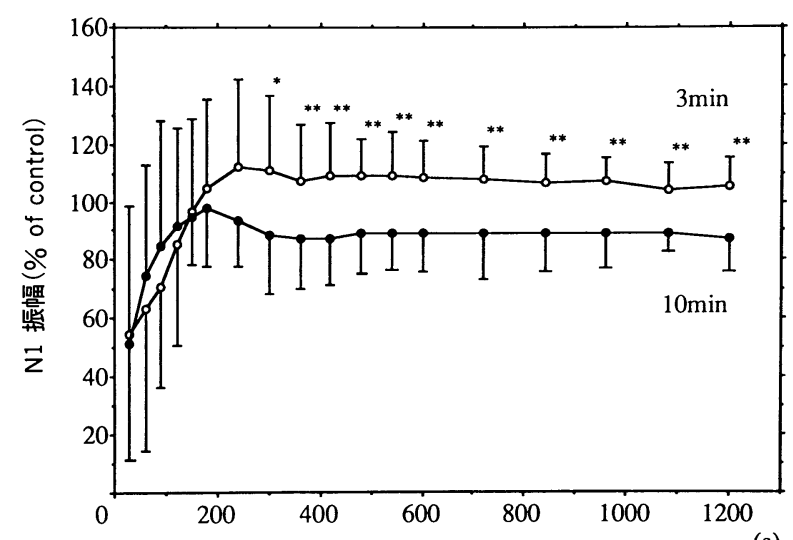

図 2 遮断解除後の N1 潜時, N2 潜時および N1 振幅の回復過 程

control は遮断前の N1 潜時, N2 潜時および N1 振幅と した.

$*: \mathrm{p}<0.05,{ }^{* *}: \mathrm{p}<0.01$

られる。したがって，N1，N2 の変化よりある程度, 蝸 牛血流動態を予測することが可能である. 今回の結果か らは 3 分間の蝸牛血流障害で $\mathrm{N} 1, \mathrm{~N} 2$ が消失する場合に
は残存血流率は約 $40 \%$ であり，N1 振幅が $60 \%$ で減少 し， N1 潜時， N2 潜時が血流障害前の潜時よりそれぞ れ $6 \% ， 8 \%$ 延長した場合には残存血流率は約 $50 \%$ と推 測することができる.

蝸牛血流減少による N1, N2 の変化として注目すべき ことは，それぞれの変化の程度には若干の違いがあるも のの N1，N2 がほぼ同時に同じよらな変化を示すことで ある. $\mathrm{AN}$ 摘出時の $\mathrm{ABR}$ を用いた術中モニタリング所 見やイヌを用いて $\mathrm{AN}$ のシュレーション手術の検討 では，蝸牛神経障害では N1 には変化を認めず， N2 潜 時が延長すると報告されている35)36)，実際の手術操作で は蝸牛血流障害と蝸牛神経障害が混在し, 術中モ二タリ ングでもより複雑な変化を示すと考えられるが，これら の検討から N1，N2 が同様の変化を示す場合には主に蝸 牛血流障害を, N1 が変化せずに N2 のみが障害される 場合には蝸牛神経の障害を想定することができる.

近年，術中聴力モニタリングに際して ABR や蝸電図 と蝸牛血流の同時モニタリングが検討されている．ヒト の蝸牛骨包はモルモットに比べて厚いために LD 血流計 での測定には改善すべき点も少なくないが37)38)，LD 法 を用いた術中蝸牛血流モニタリングは今後検討すべき方 法であると考えられる.

\section{内耳動脈，蝸牛神経の形態学的, 組織学的検討}

本稿では，我々がこれまで行ってきた正常例での内耳 動脈の走行と聴神経腫瘍例の前庭, 蝸牛神経病理に関す る研究を中心に述べる.

1. 正常例での内耳動脈の走行と分枝

内耳動脈は，AICA から分枝した後，内耳道内を走行 して内耳へ血流を供給する動脈である.内耳動脈は他の 血管系との吻合を持たないため，この血管が傷害を受け ると内耳は虚血性変化を起こす. 従って, AN 手術で聴 力保存を成功させるためには，手術時に蝸牛神経と共に 内耳動脈を保存することが必要となる．小脳橋角部での AICA の走行，および内耳動脈の起始部位は個体差が大 きいことは既に述べた通りである28)391 41)。多くの例で は，AICA は内耳道孔部でループを形成し，顔面神経と 第UIII脳神経の間，またはこの両神経の下方を走行し，1 本をたは 2 本の内耳動脈を分枝する.

我々は聴力保存手術の立場から，内耳道内の内耳動脈 と第UIII脳神経の立体的位置関係を明らかにすることが重 要と考光, 正常例 ( 7 耳)のヒト側頭骨連続切片標本より 
コンピュータ 3 次元再構築画像を作成し, 解剖学的位置 関係について検討した42). この結果, 内耳道内において は，第UIII脳神経と内耳動脈との位置関係は個体差が少な く, 特に内耳道底付近では各神経と内耳動脈の主要 3 分 枝(蝸牛動脈, 前庭蝸牛動脈, 前前庭動脈) との位置関係 は一定であり, 蝸牛動脈は蝸牛神経の中心部を走行, 前 庭蝸牛動脈は下前庭神経の後面を走行, 前前庭動脈は上 前庭神経の前面を走行していた. 内耳道孔付近では, 内 耳動脈が 1 本の場合 ( 7 耳中 3 耳) は顔面神経と第UIII脳神 経の間を走行， 2 本の場合 ( 7 耳中 4 耳) は 1 本の場合の 走行に加えて, 他の 1 本の内耳動脈が第UII脳神経の後下 面を走行していた. 聴力保存を目的とする AN 手術で は, 腫瘍を顔面神経, 蝸牛神経と剥離, 摘出する際に上 述した内耳動脈とその分枝の走行を意識して，傷害しな いよう手術操作を行らことが聴力保存の成功率を高める ために重要である.

\section{2. $\mathrm{AN}$ 症例の第UIII脳神経病理}

Schuknecht ${ }^{43)}$ は側頭骨病理標本での所見から, AN による聴平衡覚障害の病態として，1)蝸牛神経が腫瘍 に圧迫されて変性する，2)内耳道内血管が腫瘍に圧迫 されて内耳の虚血変性が起こる，3)内耳液の生化学的 変化が起こる，といら 3 つのメカニズムを提唱した. し かし側頭骨病理標本での研究では死後変化, 抗原活性の 低下, 脱灰の影響, セロイジン包埋連続標本作成のため の制約などがあり，神経系組織の詳細な検討は困難であ った.

我々は $\mathrm{AN}$ 症例での第VIII脳神経の病態をより明確に することが必要であると考え, AN の手術時に採取され た新鮮な前庭, 蝸牛神経の組織所見を光顕, 透過型電顕, 免疫組織学的手法を用いて検討した。 また，耳疾患のな い6 症例 (12耳)の第UIII脳神経を病理解剖時に採取し, 正 常コントロールとして比較した.

（1）䖮牛神経, 前庭神経への腫瘍浸潤

AN は神経䩗腫であり，良性腫痬であるが，隣接する 第VIII脳神経(蝸牛神経, 前庭神経)への腫瘍浸潤が報告さ れている ${ }^{44) 45)}$ ，我々は，この腫瘍浸潤の頻度と程度を明 らかにするため, 各神経とそれに付着した腫瘍が一塊と して摘出された検体で, 組織学的に腫瘍浸潤について検 討した46). ただし蝸牛神経での検討は, 聴力保存の適応 外の症例に限定された.この結果, 蝸牛神経 (6 検体)で は神経への腫瘍浸潤がないものが 2 検体, 軽度の腫瘍浸 潤があるものが 2 検体, 高度の腫瘍浸潤が認められたも
のが 2 検体(図 3 )であった. 前庭神経(25検体)では腫瘍 浸潤がないものが 5 検体, 軽度の腫瘍浸潤があるものが 11 検体，高度の腫瘍浸潤が認められたものが 9 検体であ った. 蝸牛神経への腫瘍浸潤がない場合には腫瘍を全摘 しても聴力保存ができる可能性がある. しかし, 軽度で あっても蝸牛神経に腫瘍浸潤がある場合には腫瘍の全摘 により蝸牛神経障害は避けられず，聴力保存は困難とな る. 蝸牛神経に浸潤した部分の腫瘍を少量残すことによ り, 蝸牛神経の障害を最小限にすることも考えられるが, この場合は残存腫瘍が再び増大して再手術を要する危険 性がある。また前庭神経への腫瘍浸潤は高頻度であるた め, 腫瘍摘出時には腫瘍再発を予防するために隣接する 前庭神経は切除することが望ましいと考えられた。

(2) 第 VIII脳神経の中枢と末梢の移行部 (TR : transitional region) におけるグリオーシス

脳神経は稀突起膠細胞が髄䩗を形成する中枢神経系と シュワン細胞が髄鞘を形成する末梢神経系とから構成さ れており，ランビェ絞輪を境に中枢から末梢へ移行して いる．第UIII脳神経は他の脳神経と比較して中枢神経系の 部位が長く，TRはほぼ内耳道孔部に位置している47). TR は外部からの物理的刺激に対して脆弱性が高いと考 えられて扣り ${ }^{48)}$ ，またこの部位は聴神経腫瘍による圧迫， 浸潤を最も強く受ける部位である ${ }^{49)}$.

$\mathrm{AN}$ 症例の第UIII脳神経 TR の病理所見を明らかにする ため，AN 手術時に採取した第VIII脳神経 TR 所見と正常 例の TR 所見とを比較した ${ }^{50)}$. AN 症例では正常例に比 較してTRに拈ける有䯣神経線維の密度が低く, 線維 性アストロサイトからなる中枢性グリア組織の増殖(グ リオーシス)が認められた(図 4).TRの中心部では毛 細血管の密度が低いが, TRの末梢部分では高かった. AN より採取した第UIII脳神経でTR の検討が可能であっ た10検体で， 7 検体では軽度のグリオーシスが，他の 3 検体では中等度のグリオーシスが認められた.グリオー シスは腫瘍の圧迫により生じた神経変性に対する修復反 応でこれに伴って神経内血管分布の変化が生じたと考え られた．TRにはランビェ絞輪が集中しているため代謝 活性が高く, この部位での毛細血管密度の低下は神経代 謝に悪影響を及ぼすと考えられる．一方，TR末梢で局 所的に毛細血管密度が上昇することは，この部位への外 力により血管障害が生じやすくなっていると考学られる。 以上より $\mathrm{AN}$ 手術に際しては, TR の存在する内耳道孔 の部位での手術操作を特に慎重に行ら必要があると考学 


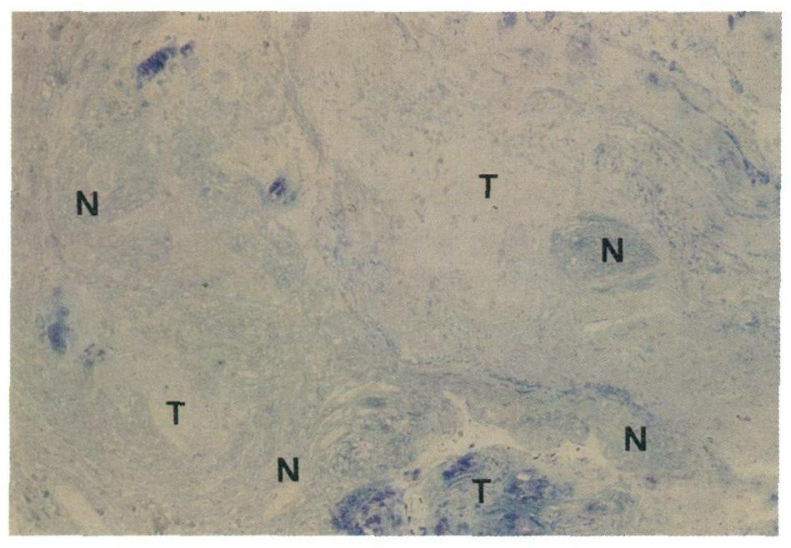

図 3 蝸牛神経への高度腫瘍浸潤 (原倍率 $\times 100$ ) $\mathrm{T}$ : 腫瘍, $\mathrm{N}$ : 神経. メチレンブルー染色.

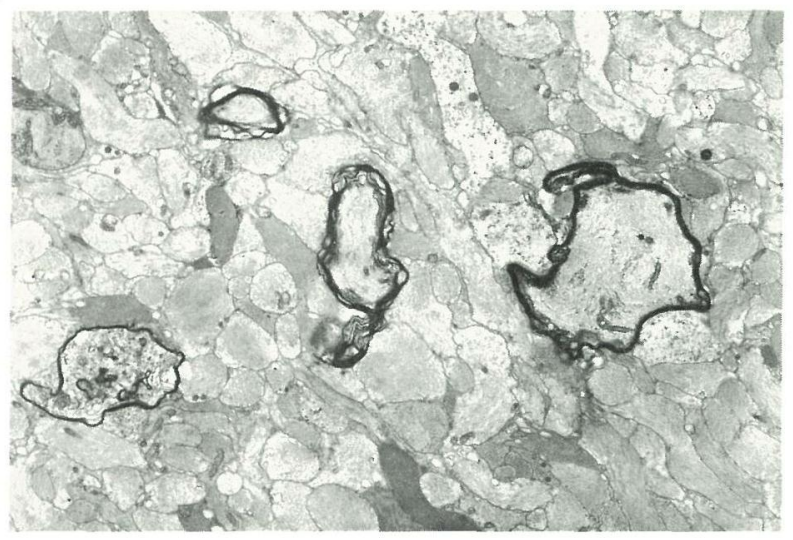

図 4 TR での線維性アストロサイトの増殖(原倍率 $\times 3000$ ) 透過型電顕.

られた。

（3）第UII脳神経から $\mathrm{AN}$ 几の血管新生

ANを含屯固形腫瘍が，数立方ミリメートル以上の体 積に成長するためには，血管新生が必要となる51)。ヒ卜 $\mathrm{AN}$ 組織をヌードマウスに移植すると，移植された腫瘍 の成長と腫瘍表面の血管新生の程度とが良く相関するこ とが報告されている52).

我々は第叫脳神経とそれに付着する AN が一塊とし て採取できた33検体を用いて，腫瘍と神経の間の血管所 見について組織学的に検討した ${ }^{53)}$. 光顕による観察で腫 瘍と神経の境界部に血管が法とんど認められない検体を グレード1, 多数の毛細血管が認められる検体をグレー ド2, 多数の毛細血管, 細静脈, 細動脈が密集して認め

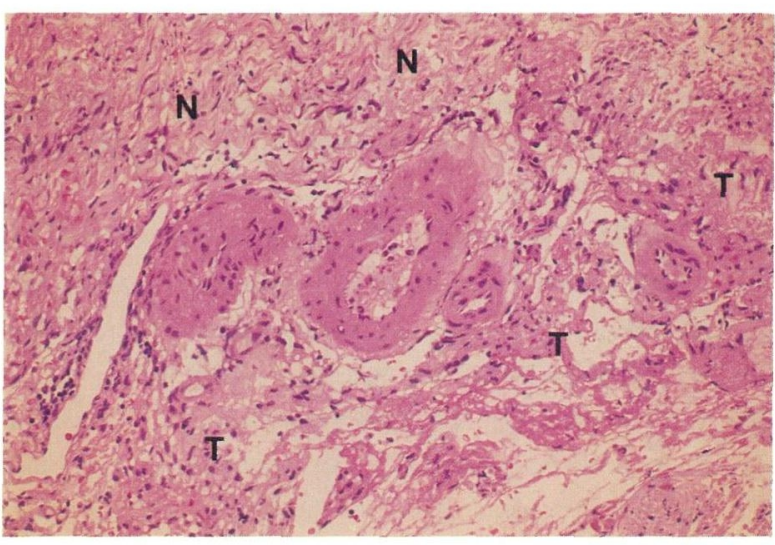

図 5 腫瘍と神経の境界部の新生血管 (原倍率 $\times 100)$

$\mathrm{T}$ ：腫瘍， $\mathrm{N}$ ：神経. ヘマトキシリン・エオジン染色.

られる検体をグレード3（図５）と評価したところ，グ レード 1 が 21 検体，グレード 2 が 6 検体，グレード 3 が 6 検体であった。グレード 2 抒よびグレード 3 と評価さ れた検体では，毛細血管内腔の拡大，内皮細胞の増殖が 認められ, 細静脈之細動脈の血管壁構造にも異常が認め られた，グレード 3 の検体では，密集した血管の周囲に 高度の線維化を伴ら例が認められた。グレード 2 とグ レード 3 に分類された 12 検体に抢ける腫瘍と神経の間の 血管の増加は，AN により第四脳神経からの血管新生が 誘導された結果と考学られた。境界部の新生血管は第叫 脳神経と腫瘍の両者に血流を供給しているため, 腫瘍摘 出によりこの血管が障害を受けると, 第䜣脳神経にも循 環障害が生じる。そのため, たと光 $\mathrm{AN}$ 摘出後に蝸牛 神経が保存されても，神経と腫瘍の間の新生血管が高度 に発達した症例では聴力の悪化が起こる可能性がある. また新生血管はその血管径に比して血管壁が薄く, 血管 壁の構成もしばしば不完全であるなど構造が脆弱であり， 破綻して出血をきたしやすいと考光られる。グレード3 の検体では新生血管には高頻度に線維化が伴っていたが, これは新生血管からの出血に対する反応である可能性が 考兄られる.AN では突発性難㯖に類似した難聴を呈す る症例があり,この病態の 1 つとして新生血管からの出 血による第壮脳神経の浮腫, 循環障害が考兄られた。

\section{参考文献}

1) 神崎 仁：聴神経腫瘍手術に持ける聴力保存の問題点. 耳 鼻臨床 $81: 153 \sim 161,1988$. 


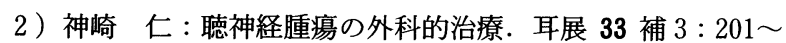
$528,1990$.

3 ）神崎 代：聴神経腫瘍における顔面神経保存 一術中神経 刺激兼用手術器具(探針および鋏)の開発一. 頭頸部外科 $4: 141 \sim 146,1994$.

4 ) Arriaga MA and Marks CS : Simultaneous cochlear implantation and acoustic neuroma resection; imaging considerations, technique and functional out come. Otolaryngol Head Neck Surg $112: 325 \sim 328,1995$.

5 ) Thedinger BA, Cueva RA and Glasscock ME : Treatment of an acoustic neuroma in an only-hearing ear; case reports and considerations for the future. Laryngoscope $103: 976 \sim 980,1993$.

6 ) Fischer G, Fischer $\mathrm{C}$ and Remond J : Hearing preservation in acoustic neuroma surgery. J Neurosurg $76: 910 \sim 917$, 1992.

7 ) Samii M : Personal communication. April, 1996.

8 ) Wigand ME, Haid T and Berg $\mathrm{M}$ : The enlarged middle cranial fossa approach for surgery of the temporal bone and of the cerebellopontine angles. Arch Otorhinolaryngol $246: 299 \sim 302,1992$.

9 ) Tos $\mathrm{M}$ and Thomsen $\mathrm{J}$ : The price of preservation of hearing in acoustic neuroma surgery. Ann Otol Rhinol Laryngol $91: 240 \sim 245,1982$.

10) Kanzaki J, O-Uchi T, Ogawa $K$, et al : Hearing preservation by the extended an non-extended middle cranial fossa approach for acoustic neuroma. Skull Base Surg 4 : 76 81, 1994.

11) Gardner $\mathrm{G}$ and Robertson $\mathrm{JH}:$ Hearing preservation in unilateral acoustic neuroma surgery. Ann Otol Rhinol Laryngol $97:$ 55 66, 1988.

12) Shelton $C$, Brackmann DE, House WF, et al : Acoustic tumor surgery ; prognostic factors in hearing conservation. Arch Otolaryngol Head Neck Surg 115 : 1213 1216, 1989.

13) Jannetta PJ, Moller AR and Moller MB : Technique of hearing preservation in small neuromas. Ann Surg 200 : 513 523, 1984.

14) Silverstein $\mathrm{H}, \mathrm{McDaniel} \mathrm{A}$, Norrell $\mathrm{H}$, et al : Hearing preservation after acoustic neuroma surgery with intraoperative direct eighth cranial nerve monitoring ; part II. classification of results. Otolaryngol Head Neck Surg $95: 285 \sim 291,1986$.

15) Sanna M, Zini C, Gamoletti R, et al : Hearing preservation; a critical review of the literature. Acoustic Neuroma (ed by Tos M and Thomsen J). Proceedings of the first international conference on acoustic neuroma. pp 631 638, Kugler Publications, Amsterdam/New York,
1992.

16) Glasscock ME, Hays JW, Minor LB, et al : Preservation of hearing in surgery for acoustic neuromas. J Neurosurg $78:$ 864 870, 1993.

17) Nadol JB, Levine R, Ojemann RG, et al : Preservation of hearing in surgical removal of acoustic neuromas of the internal auditory canal and cerebellopontine angle. Laryngoscope $97:$ 1287 1294, 1987.

18) Ogawa K, Kanzaki J, O-Uchi T, et al : Preoperative findings and hearing preservation in acoustic neuroma surgery. Acta Otolaryngol Suppl (Stockh) $487: 30 \sim 35$, 1991.

19) Shelton C, Hitselberger WE, House WF, et al : Hearing preservation after acoustic tumor removal long-term results. Laryngoscope $100: 115 \sim 119,1990$.

20) McKenna MJ, Halpin C, Ojemann RG, et al : Long term hearing results in patients after surgical removal of acoustic tumors with hearing preservation. Am J Otol $113: 134 \sim 136,1992$.

21) Tucci DL, Telian SA, Kileny PK, et al : Stability of hearing preservation following acoustic neuroma surgery. Am J Otol $15:$ 183 188, 1994.

22) Goel A, Sekha LN, Langheinrich W, et al : Late course of preserved hearing and tinnitus after acoustic neuroma surgery. J Neurosrug $77: 685 \sim 689,1992$.

23) Kanzaki J, Ogawa K, Ogawa S, et al : Audiological findings in acoustic neuroma. Acta Otolaryngol Suppl (Stockh) $487:$ 125 132, 1991.

24）大平貴之, 井端由紀郎, 中務正志, 他：聴神経腫瘍に执け る聴力保存と手術中電気生理学的モニタ一. 脳神経 40 : $553 \sim 556,1988$

25) Yingling $\mathrm{CD}$ and Gardi JN : Intraoperative monitoring of facial and cochlear nerves during acoustic neuroma surgery. Otolaryngol Clin North Am 25 : 413 448, 1992.

26）小川 郁：実験的蝸牛循環障害に护ける蝸牛血流動態と蝸 電図の変化. 慶應医学 $71: 321 \sim 335,1994$.

27) Randolf H-B, Haupt $\mathrm{H}$ and Scheibe F : Cochlear blood flow following temporary occulusin of the cerebellar arteries. Eur Arch Otorhinolaryngol 247 : 226 228, 1990.

28) Sugita M, Masutani H, Moriguchi M, et al : Distribution of arteries from brain stem to inner ear around the internal auditory canal. Acta Otolaryngol Suppl (Stochk) $486: 45$ $\sim 52,1991$

29) Ren T, Nuttal AL and Miller JM : Contribution of the anterior inferior cerebellar artery to cochlear blood flow in guinea pig ; a model-based analysis. Hear Res 71 : 91 97, 1993.

30) Fernandez $\mathrm{C}$ and Alzate R : Modifications of cochlear 
responses by oxygen deprivation. Arch Otolaryngol 69 : 82 94, 1959.

31) Perlman HB, Kimura $R$ and Fernandez $C$ : Experiments on temporary obstruction of the internal auditory artery. Laryngoscope $69: 591 \sim 613,1959$.

32) Konishi T, Butler RA and Fernandez $\mathrm{C}$ : Effects of anoxia on cochlear potentials. J Acoust Soc Am $33: 349 \sim 356$, 1961.

33) Kimura $R$ and Perlman HB : Arterial obstruction of the labyrinth ; part I . cochlear changes. Ann Otol $67: 5 \sim 40$, 1958.

34) Kusakari J, Kambayashi J, Kobayashi T, et al : The effect of transient anoxia upon the cochlear potentials. Auris Nasus Larynx 8 : 55 64, 1981.

35) Levine RA, Ojemann RG, Montgomery WW, et al : Monitoring auditory evoked pontentials during acoustic neuroma surgery ; insights into the mechanism of the hearing loss. Ann Otol Rhinol Laryngol 93 : 116 123, 1984.

36) Sekiya $T$ and Moller AR : Cochlear nerve injeries caused by cerebellopontine angle manipulations; an electrophysiological and morphological study in dogs. J Neurosurg $67: 244 \sim 249,1987$.

37) Scheibe F, Haupt H, Berndt H, et al : Laser light transmission and laser Doppler flow measurements on the human, rat and guinea pig cochlea. Eur Arch Otorhinolaryngol $247: 20 \sim 23,1990$.

38) Miller JM, Bredberg G, Grenman R, et al : Mearsurement of human cochlear blood flow. Ann Otol Rhinol Laryngol $100: 44 \sim 53,1991$

39) Sunderland $\mathrm{S}:$ The arterial relations of the internal auditory meatus. Brain $68: 23 \sim 27,1945$.

40) Mazzoni A : Internal auditory canal arterial relations at the porus acusticus. Ann Otol $78: 797 \sim 814,1969$.

41) Martin RG, Grant JL, Peace D, et al : Microsurgical relationships of the anterior inferior cerebellar artery and the facial-vestibulocochlear nerve complex. Neurosurgery $6: 483 \sim 507,1980$.

42) Matsunaga T, Igarashi $M$ and Kanzaki $J$ : The course of the internal auditory artery and its branches; computeraided three-dimensional reconstructions. Acta Otolaryngol Suppl (Stockh) $487: 54 \sim 60,1991$.
43) Schuknecht HF : Vestibular schwannoma. Pathology of the Ear. pp 425 436, Harvard University Press, Cambridge, Mass, 1974.

44) Ylikoski J, Collan Y, Palva T, et al : Cochlear nerve in neurilemomas; audiology and histopathology. Arch Otolaryngol Head Neck Surg $104: 679 \sim 684,1978$.

45) Neely JG : Gross and microscopic anatomy of the eighth cranial nerve in relationship to the solitary schwannoma. Laryngoscope $91:$ 1512 1531, 1981.

46) Matsunaga T, Kanzaki J and Igarashi $M$ : The limitations of hearing preservation in acousticc neuroma surgery; histological study of the interface between the eighth cranial nerve and the tumor. Acta Otolaryngol (Stockh) $115: 269 \sim 272,1995$.

47) Bridger MWM and Farkashidy J : The distribution of neuroglia and Schwann cells in the 8th nerve of man. J Laryngol Otol 94 : 1353 1362, 1980.

48) Matsunaga $T$, Kanzaki J and Hosoda $Y$ : Ultrastructure of asrocytes in the transitional region of the human eighth cranial nerve. Hear Res 76 : 118 126, 1994.

49) Matsunaga $T$, Igarashi $M$ and Kanzaki $J$ : Temporal bone pathology of acoustic neurinoma (unilateral and bilateral) in relation to the internal auditory canal surgery. Acta Otolaryngol Suppl (Stockh) $487: 61 \sim 68,1991$.

50) Matsunaga T, Kanzaki J and Hosoda Y : Gliosis of the eighth nerve transitional region in patients with cerebellopontine angle schwannoma. Acta Otolaryngol (Stockh) $114:$ 393 398, 1994.

51) Folkman $\mathrm{J}:$ What is the evidence that tumors are angiogenesis dependent? JNCI $82: 4 \sim 6,1990$.

52) Lee JK, Kim TS, Chiocca EA, et al : Growth of human schwannomas in the subrenal capsule of the nude mouse. Neurosurgery $26: 598 \sim 605,1990$.

53) Matsunaga T, Kanzaki J and Hosoda $Y$ : Angiogenesis from the eighth cranial nerve to vestibular schwannomas. Acta Otolaryngol (Stockh) $116: 52 \sim 58,1996$.

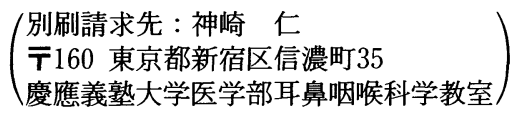

